\title{
Impact of Teacher Professional Development on Student Attitudes and Experiences in School Learning - A Case Study of Oman
}

\author{
Amira Al Shabibi, Aisha Al Mantheri and \\ Bahia Al Rashdi \\ The Specialised Centre for Professional Training of Teachers \\ MOE, Muscat, Oman
}

\begin{abstract}
The ultimate goal of teacher professional development is to improve students' learning skills and learning outcomes. Students are the end-users of teaching and education. Thus, it is of utmost relevance to get information on how students experience the instruction of teachers who have participated in professional development and inservice programmes. In this study, the impact of participation in teachers' professional training is examined in schools in Oman. The sample of the study consists of 6000 students: 3176 students of teachers who had participated in training, and 2824 students of teachers who had not received the training. The student questionnaire was designed to provide insight into how the training received by the teacher affects student attitudes towards learning and schooling. An independent sample t-test was conducted to determine if there were differences in attitudes towards learning between students of trained teachers and non-trained teachers. The results show statistically significant differences between students' attitudes of students of trained teachers.
\end{abstract}

Keywords: Teaching; teacher professional development; learning outcomes; students' attitudes.

\section{Introduction}

In specialised literature, the area of students' learning process has attracted more and more interest of researchers and specialists in the educational field (Apfelthaler et al., 2006). Research shows that students' attitudes towards learning and their enjoyment of the subject affects their learning process and their performance (Anghelache, 2013; Mazana, Montero \& Casmir, 2019). At the same time, literature proved a positive relationship between students' attitudes towards learning and classroom instruction including effective pedagogical techniques that enhance the enjoyment of learning (Anghelache, 2013; Davadas \& Lay, 2018; Hooper, Mullis, Martin and Fishbein,2019; Mazana et al., 2019). 
The University of Cambridge (2010) report Review and recommendations acknowledged the positive attitude of Omani students' to their learning by reporting that Omani students "... are diligent, respectful and clear in their answers of questions; behaviour in class is excellent and relationships between teachers and students are also extremely good" (The University of Cambridge, 2010, p.25) “Omani children enjoy going to school”.

However, although the Omani education policy has succeeded to expand access to education, it has been less successful in improving the level of learning. Learning outcomes lag behind the international average as revealed in international assessments such as the Trends in International Mathematics and Science Study (TIMSS), and the Progress in International Reading Literacy Study (PIRLS) managed by the International Association for Evaluation of Educational Achievement (IAE 2012a; 2012b; 2016a; 2016b). Poor learning outcomes consistently revealed in international evaluations have been a principle concern for the Ministry of Education in Oman. It is generally accepted that teacher preparation in Oman does not prepare teachers adequately with the skills needed for the teaching profession and in-service training has been poorly planned and scattered in nature (Al Jabri, Silvennoinen \& Griffiths, 2018). The World Bank (2012) report The Drive for Quality suggested two main priorities for Omani education to focus on: firstly, creating a culture of high standards, and secondly developing the pedagogical capacity of the teaching force. One of the areas the report suggests is to enhance professional skills focusing on in-service teacher training for quality learning.

In an attempt to reform the educational system in Oman, the Ministry of Education has had a series of developmental initiatives in recent years ( $\mathrm{Al}$ Shabibi \& Silvennoinen, 2018). These initiations included:

- Developing curriculum and performance standards to provide benchmarks for the educational levels for each grade and age range. It helps to evaluate the performance of schools, students and staff.

- Establishing a National Assessment Centre to take the responsibility of developing the assessment system as well as the qualification systems. It aims at producing valid and reliable assessment instruments that depend on statistical analyses and research capabilities. An online platform for assessment was also activated.

- Establishing The Specialised Centre for Professional Training of Teachers (SCPTT) with the responsibility of addressing the training needs of all staff working in the education sector. The centre aims to develop the skills and confidence and motivation levels of educators and administrators by providing them with sustained, intensive and accredited professional development. Additionally, SCPTT was to be responsible for setting professional standards for the teaching profession (SCPTT, 2016). The standards are an essential development in helping to clarify the roles of teachers and principals, to evaluate staff performance and to develop methods for further professional improvement. 
SCPTT started providing in-service training for teachers in 2014. It is recognised that it will take time for the expected improvement in training to impact on learning outcomes. Hence; in this study, we aim to examine whether there has been any change in students' attitudes and experiences related to school learning and school work as a result of teachers' participation in the newly organised inservice training. This is done by comparing two groups of randomly selected pupils: (1) pupils whose teachers have participated in the recently organised inservice training, and (2) pupils whose teachers have not participated in the training. Thus, to examine the possible change in attitudes, a control group of pupils is used. The study also investigates if the teacher's work experience and his/her gender affects pupils' attitudes.

Before presenting the empirical results from the large survey on pupils' attitudes and experiences, a short description of the schooling and education system in Oman will be presented, and some related findings from international literature will be discussed.

\subsection{Schooling in Oman}

Oman's educational system is described as one of the fastest-growing worldwide in terms of students' enrolment and improvements in teacher qualifications. The world Bank (2001) report regarded this development in Omani educational system between 1970 and 2000 as "unprecedented" and "unparalleled by any other country" (World Bank, 2001). Today, all members of young age cohorts attend 10 years of basic education and two years of post-basic education.

As a result of the quantitative expansion of the education system and the provision of widespread access to educational services by the 1990s, in the new millennium the focus in education policy was shifted from quantity to improving quality. The most important qualitative improvements targeted with the initiation of the Basic Education system were:

- Introducing new curricula design

- Initiating new subjects such as "Life Skills" and "Educational Technology"

- Starting English language teaching from Grade 1

- Placing more focus on the teaching of Mathematics and Science

- Making the school day as well as the school year longer

- Establishing new student assessment systems

- Increasing the quality of professional development in the whole education sector (MOE, 2006).

The Basic Education system also identified the need to reform the learning environment in the classroom. Teachers were encouraged to promote a childcentred environment that encourages cooperative learning, peer work, fieldwork, inquiry, active dialogue and discussion (Al Kharusi \& Atweh, 2008).

Despite developments in the content and structure of schooling and progress in the formal qualifications of teachers, the educational system in Oman continues 
to produce lower than expected student outcomes. Although Omani students showed positive progress in TIMSS 2015 test scores, they are still significantly under-performing by international standards (MOE, 2018a; MOE, 2018b). Far greater improvements are required to bring Omani student performance in-line with international standards. Evaluative reports and studies have highlighted several factors causing this. The first relates to the overcrowded curriculum that led to narrow and boring delivery to students (New Zealand Education Consortium, 2017) as the emphasis is highly on knowledge acquisition and retrieval rather than on developing higher-order thinking skills (CfBT/NfER, 2012) with insufficient depth of post-basic curriculum courses (World Bank, 2012). As a result, the curriculum does not prepare students for the labour market and society at large (Al-Maskri, Al-Mukhini, \& Amzat, 2012). Both the CfBT/NfER (2012) study and the University of Cambridge (2010) report highlight that tackling differentiation for students' abilities, both pedagogically and in the curriculum was rare.

The second factor causing poor student learning outcomes is that the initial teacher preparation is highly academic in content and lacks training in practical skills (World Bank, 2012). For example, the CFBT/NFER (2012) study concluded that teachers are offered insufficient training on the implementation of the learner-centred approach as well as on fostering higher-order thinking skills. As a result, despite the promotion of student-centred learning approaches, their implementation has tended to be confined to cycle one schools and in a small number of cycle two girls' schools (New Zealand Education Consortium, 2017; University of Cambridge, 2010). Teachers face difficulties in putting strategies learnt in initial teacher education into practice in the classroom. (Al-Maskri et al., 2012.)

Finally, despite the introduction of a wider range of assessment instruments with a greater focus on continuous assessment, a summative assessment was seen to be the exclusive concern of teachers rather than formative assessment (University of Cambridge, 2010). Moreover, it was noted that marks and grades given to students are overestimated compared to their actual performance level as stated by both the World Bank (2012) report and the New Zealand (2017) report. Students have false perceptions of their performance levels. As a result, it affected students' incentive to engaging in more effort to achieve better results (Al Shabibi \& Silvennoinen, 2018).

\subsection{Learning Attitudes and Gender Difference}

Although student engagement levels have been identified as an academic challenge in Arab Gulf nations (Ashcraft, 2007; Engin \& McKeown, 2012), it has attracted little in the way of research. In a study by Fredricks, Blumenfeld, and Paris (2004) it was found that students with high effective engagement enjoy learning and like going to school. Sanchal \& Sharma (2017)'s study showed that enjoyment of Mathematics was enhanced when students learnt in a sporting context, which led to a more positive attitude towards Mathematics and higher level of engagement. The correlation was also found between students' attitudes and their performance in school (Anghelache, 2013; Mazana et al., 2019). 
Enjoyment of Mathematics and attitudes towards it predicted the students' achievement level in Mazana et al.'s (2019) study. According to Anghelache (2013), student attitudes correlate positively with factors such as personal involvement, purpose and personal achievement. Hooper et al. (2019) attributed interest in a subject and enjoying it to the intrinsic motivation to learn Mathematics and Science. TIMSS data has shown correlation between such scales and student performance level in these subjects.

One important finding from TIMSS 2015 for Oman was that the level of student engagement in mathematics and science lessons correlated positively with their performance (MOE, 2018a; 2018b). Furthermore, the TIMSS 2015 student questionnaire found that in comparison to top-performing countries, Omani students expressed significantly high confidence in their understanding of subject content. In science at grade 4, they expressed the 6th highest 'very confident' rating of the 47 participating countries, while in mathematics at grade 8 , they expressed the 10th highest 'very confident' rating of the 39 participating countries. (IEA, 2016a; 2016b.)

To elaborate on the gender gap, females have a higher level of school fulfilment than males (Nickerson \& Nagle, 2004; Tinklin, 2003; Verkuyten \& Thijs, 2002), even though male students report more positive attitudes than females towards STEM subjects (Science, Technology, Engineering and Mathematics). However, the contrast can be found in their dispositions towards school and learning in general. Many investigations demonstrate that compared to females, males report that they feel less positive about school (OECD, 2004), appreciate it less, find coursework less relevant to their needs and invest less energy in homework ((Lam, Jimerson, Kikas, Cefai, Veiga, Nelson \& Hatzichristou, 2012).

In Oman, as well as in numerous other countries, boys have much more to do on achievement than girls. Girls continue to outperform boys in every test (Logan \& Johnston, 2010). Along with the general low performance level, gender gap is an issue of great concern in Omani education policy. In the Omani context, as mentioned above, there are significant gender differences in student achievement, with girls outperforming boys on all measures of students learning outcomes. In terms of engagement, the World Bank (2012) report commented that these differences in performance levels can be attributed to a number of factors. Firstly, experiences girls and boys come through at home and school environment are different. Secondly, in a general, girls use their time more efficiently at home on doing homework and studying compared to boys. The study found that girls in grade 8 spend more time enjoying reading books and doing homework rather than watching television, videos or playing computer games, compared to boys. Finally, boys self-confidence in their abilities is high compared to their poor results. They think they are good enough. Hence, they exert less effort to develop their level of performance. Despite their poor performance, Omani boys tend to exhibit high self-confidence in their abilities, for example, in their mathematical skills (IEA, 2007). One possible explanation for this finding can be attributed to assessment practices in Omani schools and the awarding of over estimated scores which give pupils an erroneous concept 
of their true skill levels. Assessment in schools and assessment in international tests tell a totally different story about Omani students' skill levels.

An investigation conducted in Qatar's public schools on student perceptions of school and learning revealed that boys show a more negative attitude towards going to school than girls (Lee, 2016). Although these findings are from Qatar, they are pertinent to the wider Arab Gulf setting, as Arab Gulf nations have adopted similar training directions, and have faced comparable difficulties in student determination and engagement, especially among their national male populace (Barber, Mourshed \& Whelan, 2007). A number of studies have demonstrated that this phenomenon is also to be found in Western settings, and have reported a gender gap in student engagement, with young males appearing to have lower levels of engagement and more negative attitudes towards learning than females (Houtte, 2004; Lam et al., 2012; Martin, 2004; OECD, 2004).

In a study targeting younger learners in 11 primary schools in England, McGeown, Johnston, Walker, Howatson, Stockburn \& Dufton (2015) studied the relationship between young children's reading attitudes, reading confidence, enjoyment from learning to read and reading attainment; through questionnaires and assessment of word reading. A correlation was found between these elements but only reading attitude, and reading confidence caused variance in the level of success in reading. The case implies that the affective aspects of reading need to be enhanced to support young learners' development in reading. About gender differences, girls showed more positive reading attitudes than boys, which is also the case in most OECD countries (OECD, 2017).

As the learning process occurs as a result of an interaction between the learner and the learning environment (Apfelthaler et al., 2006), research highlights the correlation between students' attitudes towards learning and effective classroom instruction (Anghelache, 2013; Davadas \& Lay, 2018; Hooper et al., 2019; Mazana et al., 2019). One of the critical reasons Mazana et al. (2019) give for liking Mathematics and raising student involvement is having a good teacher. They highlight the importance of the teacher's personal and professional characteristics, including teaching for understanding, delivering enjoyable lessons. Teacher effective support and classroom instruction were also highlighted as a predictor for students' attitudes towards Mathematics by Davadas and Lay (2018). Adopting a variety of appropriate pedagogical techniques is another factor that enhances interest and enjoyment in the teaching/Learning process (Davadas \& Lay, 2018; Hooper et al., 2019; Mazana et al., 2019). Some culturally bound factors as well as other cultural-free factors determine the effective teaching strategies in enhancing student engagement (Liu \& Meng, 2009; Meng, Muñoz, Hess \& Liu, 2017).

In terms of teacher professional development, the above observations indicate the need to provide teachers with skills and knowledge on appropriate instructional strategies for learning and enhancing student engagement and 
interest in what is being taught and learnt. They also need to know how to involve both parents in their children's school learning and motivation (Kim, 2018), as well as, how to use formative methods and more realistic feedback when assessing students performance. Also, skills for providing students with more individually oriented guidance are needed in Omani schools.

\subsection{Teacher Professional Development for a Change}

Despite the existence of some excellent research that provides useful analyses of particular initiatives in the domain of teacher professional development, the literature on teacher continuous professional development (CPD) is still regarded as 'partial in its coverage', 'fragmented' and 'under-theorised' (Kennedy, 2014, p.689). Kennedy (2014) argues that a deeper and better understanding of the phenomenon needs to be pursued in a collaborative way. According to her, the research literature on CPD focuses mainly on specific contexts and models of CPD, and the characteristics of effective CPD (see also Thurlings \& den Brok, 2017). Another growing area of research is measuring the impact of CPD.

In a literature review conducted by Harvard Family Research Project to examine the connection between Teacher Professional Development (TPD) and pupil outcomes, the evidence was investigated to test the hypothesis that training and supporting teachers leads to better pupils' outcomes. The team came to the conclusion that professional development is a main key activity in the overall system of staff development. The findings also suggest that the link between the level of teacher education/ training and student achievement is more complex than has been thought. Some studies show a weak association between the two. Others have highlighted different factors affecting student outcomes beside teacher education/training, such as incentives for teachers. The results support the idea that there are many ways to link TPD with improved pupil outcomes. (Harvard Family Research Project, 2006). Killion (2006) also states that during the mid-1990s research indicated the difficulties of linking TPD with student achievement due to a large number of intervening variables.

Gersten, Taylor, Keys, Rolfhus \& Newman-Gonchar (2014) showed that out of 910 studies, only five studies met the selection criteria by the U.S Department of Education 'What Works Clearinghouse' Evidence Standards (Version 2.0). Out of these five studies, two found a positive effect between TPD and students' math proficiency; one found limited effects and two found no discernible effects.

The last decade has witnessed some changes in the conceptions of professional development, or as it has recently been referred to, professional learning (Labone \& Long, 2016; Hastie, MacPhail, Calderon \& Sinelnikov, 2015). Fraser, Kennedy, Reid \& Mckinney (2007) stated that the term 'professional development' causes confusion as it may apply to both the individual development of teachers and to the development of the profession as a whole or group of people within the profession. They referred to teachers' professional development as "the broader changes that may take place over a longer period of time resulting in qualitative shifts in aspects of teachers' professionalism" 
(Fraser et al, 2007, p.157). Accordingly, shifts have occurred recently in focus and responsibilities, as a teacher becomes responsible for his or her professional learning and for improving his or her context. According to Labone \& Long (2016), affecting student outcomes requires the development of teachers and school by professional learning.

Smith (2014) states that previous research indicates a number of crucial characteristics of quality professional development: it enhances teacher's content and pedagogical knowledge, it is ongoing and sustained, it involves active participants' engagement, it is job-embedded, and it is collaborative in nature. Hence, professional development is more than a top-down process delivered in isolated workshops, as was traditionally the case in Oman. Rather, it is a process that implements knowledge into practice through the active engagement of participants (see also Guskey, 2002). According to Martin \& Dowson (2009), recent research reviews highlight the need for teacher professional development to assist disengaged and disadvantaged students by targeting key areas such as improving teacher-student relationships since the evidence suggests that students' emotional, cognitive and behavioural engagement in class correlates with their feelings of acceptance by teachers.

The Ministry of Education in Oman has, over the years, devoted considerable attention to teacher professional development, but in response to a recent national effort to re-organise and systematise in-service training programmes in order to improve the quality of teaching and learning, a new phase in teacher professional development has emerged (Al Jabri, Silvennoinen \& Griffiths, 2018). The new stage of teachers' professional development in Oman began in 2014 with the establishment of the Specialised Centre for Professional Training of Teachers (SCPTT). The type of training provided in the centre coincides with the characteristics of the quality teachers' professional development, mentioned earlier, stated by Smith (2014).

\subsection{Research questions}

The research questions are:

1- What is the attitude of Omani pupils towards learning in schools?

2- Are there significant differences in pupils' attitudes and experiences in terms of teachers' participation in in-service training and teachers' gender?

3- Are there significant differences in pupils' attitudes and experiences in terms of teachers' participation in in-service training and pupils' gender?

\section{Method}

\subsection{Participants and procedure}

In the empirical part of this article, we examine the possible changes in pupils' attitudes to, and experiences in, school learning as a result of their teachers having attended in-service training. A panel study would be optimal to measure the degree of change, however, when this is not possible, a control group of pupils is used. Attitudes of two groups of randomly selected pupils are 
compared: pupils whose teachers have participated in in-service training and pupils whose teachers have not participated in in-service training.

The sample of the study consisted of 6000 pupils. Table (1) shows the descriptive statistics of the sample. By 'trained teachers' we mean those teachers who had participated in in-service training and by 'non-trained teachers' we mean those teachers who had not participated in in-service training.

Table 1: Descriptive statistics of the sample

\begin{tabular}{llll}
\hline Student gender & $\begin{array}{l}\text { Teacher training } \\
\text { Trained }\end{array}$ & Non-trained & Total \\
\hline Male & 1642 & 1425 & 3067 \\
Female & 1534 & 1399 & 2933 \\
Total & 3176 & 2824 & 6000 \\
\hline
\end{tabular}

It has been acknowledged that questionnaires for children can show lower data quality in comparison with adults (Fuchs, 2009), with poor reading skills being one clear reason. This problem can be overcome in research by clarifying and simplifying the questions to the students by the researchers surveying in the classroom (Borgers, Leeuw \& Hox, 2000). Moreover, compared to older children, younger children tend to respond precisely to most of the questions which leads to better data quality.

A vital phase of this research was conducting a pilot study before starting the main research. The purpose of the pilot study was to test the questionnaire to find out any problems or ambiguities with the questions. Piloting was carried out in December 2015, with data collected by three trainers/researchers from SCPTT. An all-girls cycle two school (grade 5-10, morning school) was selected for piloting. Data collection was done in four classes, using students of two trained and two non-trained teachers. Then, the instrument and its instructions were modified in-line with information received in piloting.

The data was collected on five programmes conducted at SCPTT, i.e. the Arabic expert programme for Cycle one, Science programme, Mathematics programme, New Teachers programme and Centre associates programme (which is for senior teachers from different school subjects in Cycle one, Cycle two and Post Basic schools). The data were collected during the spring of 2016 from Cycle one, Cycle two and Post Basic schools across Oman. In most cases, the students filled in the questionnaire electronically in the school's resource centre. (However, this was not possible in all schools due to network problems.) The researcher showed the students how to fill in the questionnaire electronically and read all the questions in the questionnaire clarifying anything that was unclear.

\subsection{Instrument}

A structured questionnaire with twelve questions, with a Likert-types scale to provide a number of responses in each question, was used to collect data. In our questionnaire each question contains statements to which the participants indicate their agreement or disagreement using a three-point Likert-type scale, 
ranging from never (1), sometimes (2), and always (3). Unlike the conventional Likert scale, we used Visual Analogue Scales (VAS) to identify the students' feelings. This question format can be used with open-ended and closed questions (Read \& Fine, 2005). Images of face expressions ('smileys') were used in the questionnaire to make it easier for Cycle 1 students to respond.

The 12 questions were grouped into three categories: liking school learning, pupils' views on classroom engagement and pupils' confidence in learning. Table 2 shows the categories and the questions from the questionnaire included in the categories.

Table 2: Questions categorisation

\begin{tabular}{ll}
\hline Categories & Items \\
\hline Liking school learning & $1,8,9$ \\
Views on engagement & $2,4,5,7$ \\
Confidence in learning & $3,6,10,11,12$ \\
\hline
\end{tabular}

The reliability of the questionnaire was checked using internal consistency. The results showed all items significantly correlated to the overall mean of the scale. The internal consistency of the scale, as determined by Cronbach's alpha, was 0.64 .

\subsection{Data analysis}

A quantitative method was used to analyse data obtained from the questionnaire. Using SPSS 23.0, cross-tabulation was used to determine pupils' attitudes towards school learning. Two Way AVOVA was also performed to investigate the differences in pupils' attitudes in terms of their gender and teachers' participation in in-service training.

\section{Results}

In this section, the associations of students' attitudes towards school learning with teachers' participation in in-service training, students' gender and teachers' gender are analysed. In order to find out whether teachers' participation in inservice training has an impact on students' attitudes towards learning and schooling, two groups of students are compared: those whose teachers have participated in the newly organised in-service training ('trained') and those whose teachers had not participated in the training ('non-trained').

\subsection{Pupils' attitudes towards learning.}

Pupils attitudes towards learning was assessed through investigating level of liking school learning, views on engagement, and confidence in learning, as shown in Table 2. Regarding liking school subjects, Table 3 shows that more than $70 \%$ of Omani pupils stated that they always enjoy learning their subjects, as shown in Table 3, item no. 1. Working with classmates is much more popular than working individually. About $75 \%$ of pupils always enjoy working with classmates, while only about $4 \%$ of pupils never enjoy working individually. 
Table 4 shows the pupils' engagement. Almost $68 \%$ of pupils always get the opportunity "to discuss her/his learning activities more than just answering teacher's questions", and about 75\% always get the opportunity "to express her/his opinion, to discuss and to participate in the work" while doing group work. However, a relatively large number of pupils about $(26 \%)$ always "have difficulties in understanding what is being taught in the class."

Regarding confidence in learning, approximately $60 \%$ of Omani pupils feel very confident in school leaning, as shown in Table 5.

\subsection{Teachers' gender and participation in training}

The differences between male/female and trained/non-trained teachers in individual items in the three categories was also investigated. The results of cross-tabulation on teachers' gender show that there is a clear gender effect in students' attitudes. Students of female teachers showed consistently more positive attitudes than students of male teachers. Regarding training, there are substantial differences in attitudes between students of trained and non-trained teachers. The case of female teachers, these differences are in favour of trained teachers more consistently than in the case of non-trained teachers. Students of trained female teachers reveal more positive attitudes in all items. For example, they enjoy the subjects more than students of non-trained teachers, think that the teacher appreciates their work, get help if they face difficulties in understanding what is being taught, discuss their learning activities more than just answering teacher's questions, and express their opinions to discuss and participate.

In the case of male teachers, the difference between students' attitudes of trained and non-trained teachers is slightly in favour of students of non-trained teachers. This difference is shown in items 1,8 and 9 as presented in Table 3.

Table 3: Students' attitudes on liking school learning by teachers' gender and participation in in-service training

\begin{tabular}{|c|c|c|c|c|c|c|}
\hline Item & Gender & Teacher & Never & Sometimes & Always & Total $\%$ \\
\hline \multirow{6}{*}{$\begin{array}{l}\text { Q1. Do you enjoy } \\
\text { this subject? }\end{array}$} & \multirow[t]{2}{*}{ Male } & Trained & 2.6 & 30.0 & 67.4 & 100 \\
\hline & & $\begin{array}{l}\text { Non- } \\
\text { trained }\end{array}$ & 3.6 & 28.2 & 68.2 & 100 \\
\hline & \multirow[t]{2}{*}{ Female } & Trained & 0.9 & 18.5 & 80.6 & 100 \\
\hline & & $\begin{array}{l}\text { Non- } \\
\text { trained }\end{array}$ & 0.9 & 24.0 & 75.1 & 100 \\
\hline & \multirow[t]{2}{*}{ All } & Trained & 1.6 & 23.7 & 74.6 & 100 \\
\hline & & $\begin{array}{l}\text { Non- } \\
\text { trained }\end{array}$ & 2.2 & 26.0 & 71.8 & 100 \\
\hline \multirow{6}{*}{$\begin{array}{l}\text { Q8. Do you enjoy } \\
\text { working } \\
\text { individually? }\end{array}$} & \multirow[t]{2}{*}{ Male } & Trained & 27.8 & 41.1 & 31.1 & 100 \\
\hline & & $\begin{array}{l}\text { Non- } \\
\text { trained }\end{array}$ & 21.4 & 46.0 & 32.6 & 100 \\
\hline & \multirow[t]{2}{*}{ Female } & Trained & 16.4 & 41.2 & 42.3 & 100 \\
\hline & & $\begin{array}{l}\text { Non- } \\
\text { trained }\end{array}$ & 16.6 & 43.2 & 40.2 & 100 \\
\hline & \multirow[t]{2}{*}{ All } & Trained & 21.5 & 41.2 & 37.3 & 100 \\
\hline & & $\begin{array}{l}\text { Non- } \\
\text { trained }\end{array}$ & 18.9 & 44.5 & 36.6 & 100 \\
\hline
\end{tabular}




\begin{tabular}{lllllll}
\hline $\begin{array}{l}\text { Q9. Do you enjoy } \\
\text { working with }\end{array}$ & Male & Trained & 4.0 & 23.3 & 72.7 & 100 \\
your classmates? & & $\begin{array}{l}\text { Non- } \\
\text { trained }\end{array}$ & 4.6 & 21.4 & 74.0 & 100 \\
& Female & Trained & 3.7 & 18.7 & 77.6 & 100 \\
& & $\begin{array}{l}\text { Non- } \\
\text { trained }\end{array}$ & 3.8 & 20.0 & 76.2 & 100 \\
& \multirow{2}{*}{ All } & $\begin{array}{l}\text { Trained } \\
\text { Non- }\end{array}$ & 3.8 & 20.7 & 75.4 & 100 \\
& & 4.2 & 20.7 & 75.1 & 100 \\
& & & & \\
\hline
\end{tabular}

On the other hand, students of trained teachers had more positive attitudes regarding items 2, 4, 5 and 7 (Table 4). They are more likely to discuss their learning activities more than just answering teachers' questions and to express their opinions when they are doing group work.

To summarise the findings in Table 4, it seems that pupils of trained female and trained male teachers tend to feel more engaged in learning than pupils of nontrained teachers. Pupils of trained teachers are probably taught by more active learning strategies which encourages them to be engaged in the whole lesson. This finding is supported by Skinner \& Belmont (1993), who mentions that engaged pupils are energised, focused and enthusiastic, as opposed to pupils who are disengaged who tend to be easily distracted, passive, show low attention spans and are quickly discouraged when faced with a challenging task.

Table 4: Students' views on engagement by teachers' gender and participation in inservice training

\begin{tabular}{|c|c|c|c|c|c|c|}
\hline Item & Teacher & Gender & Never & $\begin{array}{l}\text { Somet } \\
\text { imes }\end{array}$ & Always & $\begin{array}{l}\text { Total } \\
\%\end{array}$ \\
\hline \multirow{6}{*}{$\begin{array}{l}\text { Q2. Do you have difficulties in } \\
\text { understanding what is being } \\
\text { taught in the class? }\end{array}$} & Male & Trained & 11.2 & 68.1 & 20.7 & 100 \\
\hline & & Non-trained & 10.5 & 65.8 & 23.7 & 100 \\
\hline & Female & Trained & 12.9 & 55.8 & 31.3 & 100 \\
\hline & & Non-trained & 13.4 & 57.8 & 28.8 & 100 \\
\hline & All & Trained & 12.1 & 61.4 & 26.5 & 100 \\
\hline & & Non-trained & 12.0 & 61.6 & 26.4 & 100 \\
\hline \multirow{6}{*}{$\begin{array}{l}\text { Q4. Do you get to discuss your } \\
\text { learning activities more than } \\
\text { just answering the teacher's } \\
\text { questions? }\end{array}$} & Male & Trained & 5.5 & 31.3 & 63.2 & 100 \\
\hline & & Non-trained & 6.3 & 32.0 & 61.7 & 100 \\
\hline & Female & Trained & 2.8 & 23.7 & 73.5 & 100 \\
\hline & & Non-trained & 4.2 & 24.1 & 71.7 & 100 \\
\hline & All & Trained & 4.0 & 27.2 & 68.8 & 100 \\
\hline & & Non-trained & 5.2 & 27.8 & 67.0 & 100 \\
\hline \multirow{6}{*}{$\begin{array}{l}\text { Q5. When doing group work, } \\
\text { do you get to express your } \\
\text { opinion, to discuss and to } \\
\text { participate in the work? }\end{array}$} & Male & Trained & 3.8 & 30.8 & 65.4 & 100 \\
\hline & & Non-trained & 6.4 & 35.7 & 57.9 & 100 \\
\hline & Female & Trained & 2.9 & 19.3 & 77.8 & 100 \\
\hline & & Non-trained & 2.2 & 22.5 & 75.3 & 100 \\
\hline & All & Trained & 3.3 & 24.4 & 72.3 & 100 \\
\hline & & Non-trained & 4.2 & 28.7 & 67.1 & 100 \\
\hline \multirow{6}{*}{$\begin{array}{l}\text { Q7. When you do independent } \\
\text { work, do you have to wait for } \\
\text { the others to finish, with } \\
\text { nothing to do? }\end{array}$} & Male & Trained & 24.7 & 55.1 & 20.2 & 100 \\
\hline & & Non-trained & 28.0 & 51.5 & 20.5 & 100 \\
\hline & Female & Trained & 28.2 & 51.3 & 20.5 & 100 \\
\hline & & Non-trained & 28.5 & 53.4 & 18.2 & 100 \\
\hline & All & Trained & 26.6 & 53.0 & 20.4 & 100 \\
\hline & & Non-trained & 28.3 & 52.5 & 19.3 & 100 \\
\hline
\end{tabular}


Results regarding items related to confidence in learning $(3,6,10,11$, and 12) are somewhat surprising. There is a clear gender division in the association between pupils' confidence and teachers' participation in in-service training. Pupils of trained female teachers are much more confident than those of non-trained female teachers, while pupils of non-trained male teachers are more confident in their learning than pupils of trained male teachers. Indeed, in all items, students of non-trained male teachers showed more positive experiences than students of trained male teachers. They get help more often when they face difficulties in understanding what is being taught, understand better what they are expected to do when they do independent work, know what they could do to learn more in class and at home, enjoy more often working with their classmates.

Table 5: Students' confidence in learning by teachers' gender and participation in inservice training

\begin{tabular}{|c|c|c|c|c|c|c|}
\hline Item & Teacher & Gender & Never & $\begin{array}{l}\text { Sometim } \\
\text { es }\end{array}$ & Always & $\begin{array}{l}\text { Total } \\
\%\end{array}$ \\
\hline \multirow{6}{*}{$\begin{array}{l}\text { Q3. Do you get help if you } \\
\text { have difficulties in } \\
\text { understanding what is being } \\
\text { taught? }\end{array}$} & \multirow[t]{2}{*}{ Male } & Trained & 6.7 & 32.2 & 61.1 & 100 \\
\hline & & Non-trained & 5.8 & 30.5 & 63.8 & 100 \\
\hline & \multirow[t]{2}{*}{ Female } & Trained & 6.4 & 24.3 & 69.3 & 100 \\
\hline & & Non-trained & 6.0 & 28.3 & 65.6 & 100 \\
\hline & \multirow[t]{2}{*}{ All } & Trained & 6.5 & 27.9 & 65.6 & 100 \\
\hline & & Non-trained & 5.9 & 29.3 & 64.7 & 100 \\
\hline \multirow{6}{*}{$\begin{array}{l}\text { Q6. When you do } \\
\text { independent work, do you } \\
\text { understand what you are } \\
\text { expected to do? }\end{array}$} & \multirow[t]{2}{*}{ Male } & Trained & 6.0 & 43.1 & 50.8 & 100 \\
\hline & & Non-trained & 5.1 & 37.7 & 57.2 & 100 \\
\hline & \multirow[t]{2}{*}{ Female } & Trained & 2.3 & 33.3 & 64.3 & 100 \\
\hline & & Non-trained & 3.1 & 34.0 & 62.8 & 100 \\
\hline & \multirow[t]{2}{*}{ All } & Trained & 4.0 & 37.7 & 58.3 & 100 \\
\hline & & Non-trained & 4.1 & 35.8 & 60.2 & 100 \\
\hline \multirow{6}{*}{$\begin{array}{l}\text { Q10. Do you know what you } \\
\text { could do in class to learn } \\
\text { more? }\end{array}$} & \multirow[t]{2}{*}{ Male } & Trained & 5.6 & 41.2 & 53.2 & 100 \\
\hline & & Non-trained & 7.5 & 38.0 & 54.5 & 100 \\
\hline & \multirow[t]{2}{*}{ Female } & Trained & 2.9 & 26.0 & 71.1 & 100 \\
\hline & & Non-trained & 3.8 & 28.9 & 67.3 & 100 \\
\hline & \multirow[t]{2}{*}{ All } & Trained & 4.1 & 32.7 & 63.2 & 100 \\
\hline & & Non-trained & 5.6 & 33.2 & 61.3 & 100 \\
\hline \multirow{6}{*}{$\begin{array}{l}\text { Q11. Do you know what you } \\
\text { could do at home to learn } \\
\text { more? }\end{array}$} & \multirow[t]{2}{*}{ Male } & Trained & 7.0 & 36.2 & 56.8 & 100 \\
\hline & & Non-trained & 6.7 & 32.8 & 60.6 & 100 \\
\hline & \multirow[t]{2}{*}{ Female } & Trained & 3.8 & 26.6 & 69.6 & 100 \\
\hline & & Non-trained & 4.4 & 28.2 & 67.4 & 100 \\
\hline & \multirow[t]{2}{*}{ All } & Trained & 5.2 & 30.9 & 63.9 & 100 \\
\hline & & Non-trained & 5.5 & 30.3 & 64.2 & 100 \\
\hline \multirow{6}{*}{$\begin{array}{l}\text { Q12. Do you think your } \\
\text { marks are fair? }\end{array}$} & \multirow[t]{2}{*}{ Male } & Trained & 11.1 & 39.0 & 49.9 & 100 \\
\hline & & Non-trained & 10.1 & 36.0 & 53.9 & 100 \\
\hline & \multirow[t]{2}{*}{ Female } & Trained & 4.5 & 29.4 & 66.1 & 100 \\
\hline & & Non-trained & 5.8 & 31.5 & 62.6 & 100 \\
\hline & \multirow[t]{2}{*}{ All } & Trained & 7.5 & 33.7 & 58.9 & 100 \\
\hline & & Non-trained & 7.9 & 33.6 & 58.5 & 100 \\
\hline
\end{tabular}

The case of female teachers, pupils of teachers who have participated in inservice training systematically are more confident. The gender difference is especially large in item 12: $66 \%$ of pupils of trained female teachers think that their marks are always fair, while only $54 \%$ of pupils of non-trained female think 
the same way. In the case of male teachers, the effect of participation in inservice training is negative: $50 \%$ of pupils of trained male teachers and $59 \%$ of pupils of non-trained male teachers say their marks are always fair.

\subsection{Pupils' gender and teachers' participation in training}

A two-way ANOVA test was conducted to examine the effects of students' gender and teachers' training on students' attitudes (Table 6). Residual analysis was performed to test the assumptions of the two-way ANOVA. Outliers were assessed by inspection of a boxplot, $Q-Q$ plots for each cell of the design was used to assess normality and homogeneity of variances was assessed by Levene's test. There were no outliers, residuals were distributed normally, but there was the heterogeneity of variances $(p<0.001)$. The reason behind it is the heterogeneity of the sample.

The interaction effect between students' gender and teachers' participation in training on students' attitudes was not statistically significant, $F(1,5596)=$ $2.373, p=0.124$, partial $\eta 2=.000$. Therefore, an analysis of the main effect for students' gender was investigated, and it indicated that the main effect was statistically significant, $F(1,5996)=194.97, p<0.001$, partial $\eta 2=.031$. Female students $(\mathrm{M}=2.5, \mathrm{SD}=0.23)$ had more positive attitudes towards learning than male students $(\mathrm{M}=2.46, \mathrm{SD}=0.27)$ did.

Table 6: Two-way-ANOVA for students' attitudes by students' gender and teachers' training.

\begin{tabular}{lllllll}
\hline Source of variance & $\begin{array}{l}\text { Sum of } \\
\text { squares }\end{array}$ & $\mathbf{d f}$ & $\begin{array}{l}\text { Mean } \\
\text { square }\end{array}$ & F & Sig & $\begin{array}{l}\text { Partial } \\
\text { Eta } \\
\text { square }\end{array}$ \\
\hline Students' gender & 12.19 & 1 & 12.19 & 194.97 & $<.001$ & 0.31 \\
Training & 0.406 & 1 & 0.406 & 6.50 & 0.011 & 0.001 \\
Gender* training & 0.148 & 1 & 0.148 & 2.37 & 0.124 & \\
Error & 374.96 & 5996 & 0.063 & & & \\
Total & 37907.93 & 6000 & & & & \\
\hline
\end{tabular}

There was also statistically significant effects of teacher's participation in training on students' attitudes towards learning $F(1,5996)=6.499, p=0.011$, partial $\eta 2=0.001$. Students of trained teachers $(M=2.51, S D=0.25)$ showed more positive attitudes towards learning than students of non-trained teachers $(\mathrm{M}=2.49, \mathrm{SD}=0.26)$.

\section{Discussion and Conclusions}

According to results from the TIMSS and PIRLS international assessments, pupils in Oman tend to have positive attitudes towards schooling and learning, but at the same time perform poorly in mathematics, science, and literacy (MOE, 2018a; MOE, 2018b). Thus, there seems to be a serious discrepancy between learning attitudes and learning outcomes. Due to low participation rates in early childhood education, Omani pupils have spent less time in formal education compared to pupils in most other countries. Low-performance levels in 
international tests can have a detrimental effect on the future economic wellbeing of the country and are, therefore, a critical concern for Omani education policymakers. One measure is taken to help overcome this has been to organise Teachers' Professional Development (TPD) in a more systematic and comprehensive way through the establishment of the Specialised Centre for Professional Training of Teachers SCPTT with a remit to conduct in-service training for all personnel in education nation-wide.

In this article, the impact of TPD on pupils' attitudes to schooling and learning was examined. The sample of the study consisted of pupils of two groups: pupils of teachers who had participated in the newly organised in-service training and pupils of teachers who had not joined the training. A questionnaire for pupils consisted of 12 items to measure pupils' attitudes towards schooling and learning.

The results showed that female pupils have more positive attitudes toward learning than male pupils. This result is consistent with Houtte (2004), Lam et al. (2012), Martin (2004), OECD (2004), McGeown et al., (2015), Nickerson \& Nagle (2004), Tinklin (2003), and Verkuyten \& Thijs (2002). Indeed, in most countries participating in PISA, TIMSS, and PIRLS, the percentage of girls with positive attitudes towards schooling is much higher than that of boys. The difference between boys and girls in liking or disliking school has been known for decades (e.g. Tenenbaum, 1944).

The results from our questionnaire show that teachers who have recently participated in TPD contribute positively to pupils' attitudes to schooling and learning. Most likely, participation in the training programmes provides teachers with additional skills and active learning strategies focussing on pupils. These attempts reflect positively on pupils' attitudes. This result is in line with the results of Piwowar, Thiel, and Ophardt (2013).

Moreover, the study revealed that pupils of female teachers show more positive attitudes than pupils of male teachers - regardless of whether the teacher has participated in in-service training or not. This might be explained by the fact that female teachers are more interpersonally oriented and more focused on how pupils feel or process the materials, whereas male teachers are more taskoriented as they focus on delivering the materials and they think that their job finishes as soon as pupils complete the tasks (Eagly \& Johnson, 1990; Queller, 1997).

Unexpectedly, male students whose teachers had participated in training hold more negative attitudes towards their schooling than students whose (male) teachers had not undergone training. This finding might be explained in different ways. It might be that male teachers are failing to implement the desired changes in their classrooms (Al-Maskri et al., 2012). This assumption might imply that the training programmes are facing challenges to engage with male teachers. Male students may do not show interest because they feel uncomfortable with the new methods and activities their teachers are 
introducing. It could also be that they do not like the change. It might be because teachers are putting more pressure on students by applying new strategies to push them to think harder. Another explanation could be the fact that boys are generally less positive than girls about school (Lam et al., 2012; Lee, 2016).

\section{Limitations and Recommendations}

There are some limitations in this study that research may solve in future studies.

- A sample of wide- ranged student age. The study targeted students aged between 9 and 18 years. The study could not ignore younger students since some of the programmes (e.g. Arabic language) are mainly for teachers of young students. We tried to overcome this issue by using facial visual analogue scale to help young learners to respond.

- Unequal size of teaching experience groups (new teachers, 3-7 years, 8-12 years and more than 12 years), so this variable was excluded from the analysis. Since we have only one programme for new teachers and the other four training programmes in this study are for experienced teachers, we could not control the numbers of teachers in each work experience group.

- This study used cross-sectional method since we were not able to conduct a longitudinal one due to the length of time such type of research require. We solved this issue by taking a wide range of ages and classes ( 9 to 18 years) for comparison of two groups.

- Despite the poor performance in international tests, Omani pupils show positive attitudes towards schooling and learning. This attitude might be because Omani pupils respect their teachers and tend to be positive in answering the questionnaires in the absence of their teachers. Thus, using a similar tool in different cultural context would probably not produce similar results for comparison.

- Reasons behind the negative attitudes of students of male trained teachers need further investigation in future research to understand them and take action to address these negative attitudes.

Overall, teachers' training proves to be effective in changing pupils' attitudes towards learning. Yet, the planning of TPD programmes need to focus more on the strategies targeting male teachers and to encounter the gender differences in the programme materials.

\section{References}

Al Jabri, M., Silvennoinen, H., \& Griffiths, D. (2018). Teacher professional development in Oman: Challenges, efforts and solutions. International Journal of Learning, Teaching and Educational Research 17(5), 82-103.

$\mathrm{Al}$ Kharusi, B., \& Atweh, B. (2008). Civic participation and educational reform in the Sultanate of Oman (PhD's thesis). Science and Mathematics Education Centre, Curtin University of Technology, Perth, Australia.

Al Shabibi, A., \& Silvennoinen, H. (2018). Challenges in education system affecting teacher professional development in Oman. Athens Journal of Education, 5(3), 261-282. 
Al-Maskri, M. S., Al-Mukhini, S. H., \& Amzat, I. H. (2012). Improving education system in Oman through school curriculum, teaching methods and evaluation: What is needed? International Journal of Sustainable Development 3(10), 39-60.

Angheiache, V. (2013). Determinant factors of students' attitudes towards learning. Procedia- Social and Behavioral Sciences 93, 478-482.

Apfelthaler, G., Hansen, K., Keuchel, S., Muller, C., Neubauer, M., Heng Ong, S., \& Tpachai, N. (2006). Asian and European - Similar and yet different.: A comparison of students' attitudes towards learning and studying across four countries. (2006). Intercultural Communication Competencies in Higher Education and Management: Proceedings of the International Conference on Intercultural Communication Competencies, October 6-7, 2005, Singapore (pp.11-35). Singapore: Research Collection Lee Kong Chian School of Business.

Ashcraft, N. (2007). UAE pre-service teachers' motivations for entering the world of TESOL. In L. Stephenson, \& P. Davidson (Eds.), Teacher education and continuing professional development: Insights from the Arabian Gulf (pp. 27- 42). Dubai: TESOL Arabia.

Barber, M., Mourshed, M., \& Whelan. F. (2007). Improving education in the Gulf. In The McKinsey Quarterly 2007 special edition: Reappraising the Gulf States (pp. 39- 47). London: McKinsey.

Borgers, N., Leeuw, E. D., \& Hox, J. J. (2000). Children as respondents in survey research: Cognitive development and response quality. Bulletin de Méthodologie Sociologique (BMS) 66, 60-75

CfBT/NFER (Centre for British Teachers/National Foundation for Educational Research). (2012). Developing educational standards: Benchmarking report. Muscat: Ministry of Education.

Davadas, S., \& Lay, Y. (2018). Factors affecting students' attitudes towards Mathematics: A structural Equation Modelling Approach. EURASIA Journal of Mathematics, Science and Technology Education, 14(1), 517-529.

Eagly, A., \& Johnson, B. (1990). Gender and leadership style: a meta-analysis. Psychological Bulletin 108(2), 233-256.

Engin, M., \& McKeown, K. (2012). Cultural influences on motivational issues in students and their goals for studying at university. Learning and Teaching in Higher Education: Gulf Perspectives, 9(1).

Fraser, C., Kennedy, A., Reid, L., \& Mckinney, S. (2007). Teachers' continuing professional development: Contested concepts, understanding and models. Journal of In-Service Education, 33(2), 153-169.

Fredricks, J. A., Blumenfeld, P. C., \& Paris, A. H. (2004). School engagement: Potential of the concept, state of the evidence. Review of Educational Research, 74(1), 59-109.

Fuchs, M. (2009). The reliability of children's survey responses: The Impact of cognitive functioning on respondent behaviour. In Statistics Canada Catalogue no. 11-522X, Data collection: challenges, achievements and new directions. Proceedings of Statistics Canada symposium 2008. Ottawa: Canada.

Gersten, R., Taylor, M., Keys, T. D., Rolfhus, E., \& Newman-Gonchar, R. (2014). Summary of research on the effectiveness of Math professional development approaches. (REL 2014-010). Washington, DC: U.S. Department of Education, Institute of Education Sciences, National Centre for Education Evaluation and Regional Assistance, Regional Educational Laboratory.

Guskey, T. (2002). Professional development and teacher change. Teachers and Teaching, 8(3), 381-391.

Harvard Family Research Project. (2006). Pathways from workforce development to child outcome. The Evaluation Exchange, 11(4), 2-4. 
Hastie, P., MacPhail, A., Calderon, A., \& Sinelnikov, O. (2015). Promoting professional learning through ongoing and interactive support: Three cases within physical education. Professional Development in Education, 41(3), 452-466.

Hooper, M., Mullis, I., Martin, M., \& Fishbein, B. (2019). TIMSS 2019 context questionnaire framework. In TIMSS 2019 assessment frameworks (pp. 57-78). Chestnut Hills, USA: TIMMS and PIRLS International Study Center.

Houtte, M. (2004). Why boys achieve less at school than girls: The difference between boys' and girls' academic culture. Educational Studies, 30(2), 159 - 173.

IEA. (International Association for the Evaluation of Educational Achievement). (2007). TIMSS 2007 International Mathematics report. Lynch School of Education, Boston College: TIMSS \& PIRLS International Study Centre.

IEA. (2012a). PIRLS 2011 International results in reading. Chestnut Hill: TIMSS \& PIRLS International Study Centre.

IEA. (2012b). TIMSS 2011 International results in Mathematics. Chestnut Hill: TIMSS \& PIRLS International Study Centre.

IEA. (2016a). TIMSS 2015 International results in Mathematics. Chestnut Hill: TIMSS \& PIRLS International Study Centre.

IEA. (2016b). TIMSS 2015 International results in Science. Chestnut Hill: TIMSS \& PIRLS International Study Centre.

Kennedy, A. (2014). Understanding continuing professional development: The need for theory to impact on policy and practice. Professional Development in Education, 40(5), 688-697.

Killion, J. (2006). Evaluating the impact of professional development in eight steps. Harvard Family research project. The Evaluation Exchange, 11(4), 5.

Kim, S. (2018). How and why fathers are involved in their children's education: Gendered model of parent involvement. Educational Review, 70(3), 280-299.

Lam, S. F., Jimerson, S., Kikas, E., Cefai, C., Veiga, F. H., Nelson, B., \& Hatzichristou, C. (2012). Do girls and boys perceive themselves as equally engaged in school? The results of an international study from 12 countries. Journal of School Psychology, $50(1), 77-94$.

Lee, S. (2016).What motivates and engages students in the education process: An examination of Qatari students' mindset and attitudes toward going to school, learning, and future aspirations. Journal of Education and Learning, 5(3), 220-235.

Liu, S., \& Meng, L. (2009). Perceptions of teachers, students and parents of the characteristics of good teachers: A cross-cultural comparison of China and the United States. Educational Assessment, Evaluation, and Accountability, 21, 313-328.

Logan, S., \& Johnston, R. (2010). Investigating gender differences in reading. Educational Review, 62(2), 175-187.

Martin, A.J., (2004). School motivation of boys and girls: Differences of degree, differences of kind, or both? Australian Journal of Psychology, 56, 133-146.

Martin, A.J., \& Dowson, M. (2009). Interpersonal relationships, motivation, engagement, and achievement: Yields for theory, current issues, and educational practice. Review of Educational Research, 79(1), 327-365.

Mazana, M., Montero, C., \& Casmir, R. (2019). Investigating students' attitudes towards learning Mathematics. International Electronic Journal of Mathematics Education, 14(1), 207-231.

McGeown, S., Johnston, R., Walker, J., Howatson, K., Stockburn, A. \& Dufton, P. (2015). The relationship between young children's enjoyment of learning to read, reading attitudes, confidence and attainment. Educational Research, 57(4), 389_ 402.

Meng, L., Muñoz, M., Hess, K. K., \& Shujie, L. (2017). Effective teaching factors and student reading strategies as predictors of student achievement in PISA 2009: The case of China and the United States. Educational Review, 69(1), 68-84. 
MOE. (Ministry of Education). (2006). From access to success: Education for all (EFA) in the Sultanate Of Oman 1970-2005. Muscat: The Ministry of Education.

MOE. (2008). Inclusive education in the Sultanate of Oman: National report of the Sultanate of Oman. Muscat: The Ministry of Education.

MOE. (2018a). The national report. TIMSS 2015-Mathematics. Muscat: The Ministry of Education.

MOE. (2018b). The national report. TIMSS 2015-Science. Muscat: The Ministry of Education.

Muijs, D. (2004). Doing quantitative research in education with SPSS. London: SAGE Publications Ltd.

New Zealand Education Consortium. (2017). Evaluation of school system in Oman. Muscat: The Ministry of Education.

Nickerson, A. B., \& Nagle, R. J. (2004). The influence of parent and peer attachments on life satisfaction in middle childhood and early adolescence. Social Indicators Research, 66(1-2), 35-60.

OECD. (2003). Learning for tomorrow world - first results from PISA 2003. Paris: OECD Publishing.

OECD. (2017). PISA 2015 results (Volume III): Students' well-being. Paris: OECD Publishing.

Piwowar, V., Thiel, F., \& Ophardt, D. (2013). Training in- service teachers' competencies in classroom management. A quasi-experimental study with teachers of secondary schools. Teaching and Teacher Education, 30, 1-12.

Queller, D. (1997). Why do females care more than males? Proceedings of the Royal Society B: Biological Sciences, 264(1388), 1555-1557.

Read J. C. \& Fine, K. (2005, September 13th). Using survey methods for design and evaluation in child computer interaction. Paper presented on Child Computer Interaction: Methodological Research at Interact, Rome, Italy.

Sanchal, A., \& Sharma, S. (2017). Students' attitudes towards learning Mathematics: impact of Teaching in sporting context. Teachers and Curriculum, 17(1), 89-99.

SCPTT (The Specialised Centre for Professional Training of Teachers). (2016). Document of professional standards. Muscat: The Ministry of Education.

Skinner, E. A., \& Belmont, M. J. (1993). Motivation in the classroom: Reciprocal effects of teacher behaviour and student engagement across the school year. Journal of Educational Psychology, 85(4), 571-581.

Smith, G. (2014). An innovative model of professional development to enhance the teaching and learning of primary science in Irish Schools. Professional Development in Education, 40(3), 467-487.

Tenenbaum, S. (1944). Attitudes of elementary school children to school, teachers and classmates. Journal of Applied Psychology, 28(2), 134-141.

Thomas, M. (1998). Conducting educational research: A comparative view. Westport, CT: Bergin \& Garvey.

Thurlings, M. \& den Brok, P. (2017). Learning outcomes of teacher professional development activities: A meta-study. Educational Review, 69(5), 554-576.

Tinklin, T. (2003). Gender differences and high attainment. British Educational Research Journal, 29(3), 307-325.

University of Cambridge. (2010). Review and recommendations. Muscat: The Ministry of Education.

Verkuyten, M., \& Thijs, J. (2002). School satisfaction of elementary school children: The role of performance, peer relations, ethnicity, and gender. Social Indicators Research, 59, 203-228.

World Bank. (2001). The Sultanate of Oman: Cost- effectiveness study for the education sector. Washington D.C: The World Bank, Technical Cooperation Programme, Middle East and North Africa Region 
World Bank. (2012). Education in Oman: The drive for quality. Washington D.C: The World Bank. 